УДК 551.501 .81

\title{
ОБОСНОВАНИЕ ТРЕБОВАНИЙ К ДЛИНАМ ВОЛН РАДИОЛОКАЦИОННОГО МОНИТОРИНГА В ГИДРОМЕТЕОРОЛОГИЧЕСКИХ ЦЕЛЯХ
}

\author{
ДАНОВА Т. Е., ПЕРЕЛЫГИН Б. В.
}

Одесский государственный экологический университет, Украина, Одесса, 65016, ул. Львовская, 15

\begin{abstract}
Аннотация. Представлен анализ распространения электромагнитных волн различной длины в облачной и безоблачной атмосфере. Показано ослабление радиоволн 0,$8 ; 3,2 ; 5,6$ и 10,0 см в облаках различных форм, разной водности и температуры. На основе повторяемости и интенсивности опасных явлений осуществлено районирование территории Украины. Проведено обоснование использования длин волн 0,$8 ; 5,6$ и 10,0 см для радиолокационного зондирования атмосферы в рамках климатического и синоптического мониторинга. Даны рекомендации по размещению радиолокационных станций различных частотных диапазонов для обеспечения потребностей в информационном продукте гражданской и ведомственной авиации.
\end{abstract}

Ключевые слова: радиолокационный мониторинг атмосферы, длины волн, радиолокационное поле

\section{ВВЕДЕНИЕ}

Многие наблюдения в атмосфере, относящиеся к глобальной системе наблюдения за климатом (ГСНК), проводятся в рамках уже существующих систем наблюдений. Основой системы получения информации о состоянии окружающей среды является наблюдательная сеть, включающая в себя в качестве одного из элементов наземную систему стационарных и подвижных пунктов наблюдений. Эта система совмещает в себе функции климатического (основа мониторинга климата) и синоптического (основа оперативного гидрометеорологического обеспечения) мониторинга $[1,2]$.

Наиболее четкие обязательства по размещению приборов и обмену сводками реализуются национальными метеорологическими службами на уровне приземной сети метеорологических станций и сети метеорологических радиолокационных станций [1]. В настоящее время в Украине есть несколько метеорологи-

DOI: $10.20535 / \mathrm{S} 0021347016070049$

(С) Данова Т. Е., Перелыгин Б. В., 2016 ческих радиолокационных станций [3]. Совершенствование радиолокационных метеорологических наблюдений возможно только за счет построения единого радиолокационного поля. Оно обеспечит получение непрерывных как по пространству, так и по времени гидрометеорологических данных. При этом в качестве одной из первых должна быть решена задача выбора диапазонов волн для каждой метеорологической радиолокационной станции, входящей в сеть.

В разных странах, учитывая различный предлагаемый потребителю набор информационных продуктов, по-разному определялся наиболее эффективный рабочий диапазон волн метеорологических РЛС. Районирование территории Украины с целью выявления регионов с наибольшей повторяемостью опасных явлений погоды, связанных с формированием мощной конвективной облачности проведено в [4-8]. В зависимости от повторяемости опасных явлений погоды для минимизации ущерба 